2. Andersen GE, Hertel J, Tygstrup I 1981 Pulmonary fat accumulation in preterm infants. Lancet $1: 441$

3. Barson AJ, Chiswick M, Doig CM 1978 Fat embolism in infancy after intravenous fat infusions. Arch Dis Child 53:218

4. Barson AJ 1980 Safety of intralipid. Lancet 2:1021

5. Levene MI, Wigglesworth JS, Desai R 1980 Pulmonary fat accumulation after intralipid infusion in the preterm infant. Lancet $2: 815$

6. Dahms BB, Halpin TC 1980 Pulmonary arterial lipid deposit in newborn infants receiving intravenous lipid infusion. J Pediatr 97:800

7. Glomset JA, Norum KR 1973 The metabolic role of lecithin cholesterol acyltransferase: Prospective from pathology. Adv Lipid Res 11:1

8. Nicoll A, Miller NE, Lewis B 1979 High density lipoprotein metabolism. Adv Lipid Res 17:53

9. Shojania AM, Jain SK, Shohet SB 1983 Hereditary lecithin cholesterol acyltransferase deficiency: report of two new cases and review of the literature. Clin Invest Med 6:49

10. Stokke KT, Bjerve KS, Blomhoff JP, Oystese B, Flatmark A, Norum KR Gjone E Familial lecithin cholesterol acyltransferase deficiency: Study on lipid composition and morphology of tissues. Scand J Clin Lab Invest 137:93

11. Bron AJ, Lloyd JK, Fosbrooke AS, Winder AF, Tripathi RC 1975 Familia LCAT deficiency disease. Lancet 1:928

12. Frohlich J, Godolphin WJ, Reeve CE, Evelyn KA 1976 Familial LCAT deficiency: Report of two patients from a Canadian family of Italian and Swedish descent. Scand J Clin Lab. Invest 38(suppl) 150:156

13. Naito C, Teramoto T, Kato M, Watanabe T, Yamanaka T, Iwamoto A 1978 Lipid compositions of plasma major lipoproteins and lipoproteinlipase activity in hypolipidemic and hyperlipidemic siblings with familial LCAT deficiency. Scand J Clin Lab Invest 38(suppl) 150;168

14. Jain SK, Yip R, Pramanik AK, Dallman PR, Shohet SB 1982 Reduced plasma cholesterol esterifying activity in iron-deficient rats: Its possible role in the lipemia of iron deficiency. J Nutr 112:1230

15. Moorhead JF, El-Nahas M, Harry D, Persaud JW, Mayne K, Chan MK Verghese, Z 1983 Focal glomerular sclerosis and nephratic syndrome with partial lecithin: Cholesterol acyltransferase deficiency and discoidal high density lipoprotein in plasma and urine. Lancet 1:936

16. Jain SK, Mohandas N, Sensabaugh GF, Shojania AM, Shohet SB 1982 Hereditary lecithin-cholesterol acyltransferase deficiency: a heterozygous var- iant with erythrocyte membrane abnormalities. J Lab Clin Med 99:816

17. Jain SK, Mazumdar S, Subrahmanyam D 1977 Effect of phenylhydrazine on the plasma lipids of albino rats. Nuanyn-Schmiedbergs Arch Pharmaco 298:75

18. Folch J, Lees M, Sloane-Stanley GM 1957 A simple method for the isolation and purification of total lipids from animal tissues. J Biol Chem 226:497

19. Zlatkis A, Zak B, Boyle AJ 1953 A new method for the direct determination of serum cholesterol. J Lab Clin Med 41:986

20. Colton $T 1979$ Statistics in medicine. Little, Brown and Co., Boston

21. Lacko AG, Ruttenberg HL, Soloff LA 1972 On the rate of cholesterol esterification in cord blood serum. Lipids 7:426

22. Cooper RA, Gulbrandsen CL 1971 The relationship between serum lipoproteins and red cell membranes in abetalipoproteinemia: deficiency of lecithin cholesterol acyltransferase. J Lab Clin Med 78:323

23. Klimou AN, Nikiforova AA, Chistyakova AM, Magracheva EY, Anderson DW 1978 Lecithin cholesterol acyltransferase deficiency in the blood plasma of newborn. Artery 4:9

24. Andrew G, Chan G, Schiff D 1976 Lipid metabolism in the neonate 1 . The effect of intralipid infusion on plasma triglyceride and free fatty acid concentrations in the neonate. $\mathrm{J}$ Pediatr $88: 273$

25. Shennan AT, Bryan MH, Angel A 1977 The effect of gestational age of intralipid tolerance in newborn infants. J Pediatrics 91:139

26. Pereira GR, Fox WW, Stanley CA, Baker L, Schwartz JG 1980 Decreased oxygenation and hyperlipemia during intravenous fat infusions in premature infants. Pediatrics $66: 26$

27. Friedman Z, Danion A, Lamberth EL, Mann WJ 1978 Cord blood fatty acid composition in infants and in their mothers during the third trimester. $J$ Pediatr 92:461

28. Penn D, Schmidt-Somerfeld E, Wolf M 1980 Carnitine deficiency in premature infants receiving total parenteral nutrition. Early Hum Dev 4:23

29. Dhanireddy R, Hamosh M, Sivasubramaniam KW, Chowdhry P, Scanlon JW Hamosh P 1981 Post-heparin lipolytic activity and intralipid clearance in very low birth weight infants. J Pediatr 98:617

30. Levene MI 1982 Tolerance of parenteral fat in the preterm neonate. In: Wesdorp RIC, Soeters PB (ed) Clinical Nutrition '81. Churchill Livingston, New York

\title{
The Action of Dopamine upon Brown Adipose Tissue
}

\author{
G. M. MAXWELL, SILVIA CROMPTON, C. SMYTH, AND G. HARVEY \\ Department of Paediatrics, University of Adelaide, The Adelaide Children's Hospital, North Adelaide, \\ South Australia
}

\begin{abstract}
We increased the mass of interscapular brown adipose tissue in rats by dietary manipulation ("cafeteria" feeding), cold exposure, or by both. The animals were then used to determine the temperature response of the interscapular brown adipose tissue to dopamine or norepinephrine. These results, and the increase in blood glycerol values, were very similar for either catecholamine. These findings suggest that dopamine may have a role in releasing energy from brown adipose tissue similar to that of norepinephrine in the newborn infant. (Pediatr Res 19: $60-63,1985$ )
\end{abstract}

\section{Abbreviation}

BAT, brown adipose tissue

Some years ago we documented a high concentration of dopamine in the urine of human neonates (8). We postulated then that dopamine might have a homeostatic role like that of norepinephrine, which can release energy from brown adipose tissue (6). Herein we report our findings concerning the effects of dopamine upon BAT stores in the laboratory rat.

\section{MATERIALS AND METHODS}

Received April 9, 1984; accepted July 25, 1984.

Correspondence Professor G. M. Maxwell, Department of Paediatrics, University of Adelaide, Adelaide Children's Hospital, North Adelaide, South Australia 5006 .
The subjects were 32-day-old litter mate, weanling, female rats of the Porton type of the Sprague-Dawley strain. They were 
divided into four groups. Group 1 received water and standard rat food ad libitum and were maintained at room temperature of $26-27^{\circ} \mathrm{C}$. Group 2 received the same diet but were held at $4^{\circ}$ C. Group 3 animals were fed a cafeteria-type diet of high energy foods such as peanuts, chocolate, canned-meat, potato chips, etc. (12). These were also given $30 \%$ sucrose solution to drink and were held at room temperature. Group 4 animals received a cafeteria-type diet with sucrose solution but were maintained at $4^{\circ} \mathrm{C}$. The animals were housed two to three per cage and given a light/dark alternation of $12 \mathrm{~h}$. These methods were designed to increase interscapular BAT mass either by cold exposure of the animals, or by their eating a high-energy cafeteria-type diet, or by a combination of the two. The animals were weighed each day. We have previously presented the details of this method (13) which ensures steady weight-gain, ready accumulation of interscapular BAT, and good general health and survival.

The thermal response of the interscapular BAT was measured, and the catecholamine responses were compared by the following method: the animals were anesthetized with pentobarbital (7.5 $\mathrm{mg} / 100 \mathrm{~g}$ body weight) given intraperitoneally. The skin areas over the interscapular BAT pad and a lumbar muscle were shaved, and temperature-sensitive probes (Yellow Springs Instrument Co., Yellow Springs, OH, Type 400) were applied to the skin. The probes gave a response which was linear in the range $35-43^{\circ} \mathrm{C}$. The core temperature was measured by inserting another probe $4-6 \mathrm{~cm}$ into the colon. The animals were placed prone on a pad through which circulated water at $37^{\circ} \mathrm{C}$. The ambient temperature during the studies was $26 \pm 1^{\circ} \mathrm{C}$. The animals were observed for 15-30 min to ensure that the temperatures were stable in the two areas under study. In addition, we ascertained that the skin temperature in the abdominal area and flanks adjacent to the warming pad did not vary.

The method of measuring BAT and lumbar muscle temperatures is essentially similar to the classic method of measuring the response of BAT to norepinephrine in the rabbit (7), and in the rat (10), and in addition we did preliminary experiments in which the thermistors were applied to the exposed BAT or lumbar muscle. We found an excellent correlation of temperature responses thus obtained with those obtained by thermistor application to the skin. BAT and lumbar muscle temperatures were both recorded in the belief that the resting muscle has a limited ability to generate heat, and that muscle temperature changes would reflect, to some extent, the circulatory rather than the thermogenic effect of any of the drugs which we examined.

Thus, temperatures were recorded for 15-20 min to ensure that the animal was in a stable condition. Then the animal received a subcutaneous injection in the hindleg with equal volumes of one of the following: $0.9 \% \mathrm{NaCl}$ solution $(\mathrm{pH} 6.1$ ), dopamine (as Intropin, Arnar-Stone Inc., Aguadilla, Puerto Rico, $\mathrm{pH}$ 4.7), or norepinephrine (as Levophed, Winthrop, UK, $\mathrm{pH}$ 3.2). The dose of dopamine was $200 \mu \mathrm{g} / 100 \mathrm{~g}$ body weight, and of norepinephrine $25 \mu \mathrm{g} / 100 \mathrm{~g}$ body weight. Thereafter the temperature responses were measured for $120 \mathrm{~min}$ in the skin areas described above; preliminary studies with $0.9 \% \mathrm{NaCl}$ at $\mathrm{pH} 6.1$, or buffered to $\mathrm{pH} 4.7$ or 3.2 , had no effect in the control periods.

In other experiments, the $\beta$-blocker propranolol $(8 \mu \mathrm{g} / 100 \mathrm{~g})$, the $\alpha$-blockers prazosin $(4 \mu \mathrm{g} / 100 \mathrm{~g})$, or phenoxybenzamine (250 $\mu \mathrm{g} / 100 \mathrm{~g})$, and the dopamine blocker pimozide $(4.5 \mu \mathrm{g} / 100 \mathrm{~g})$ were given intraperitoneally to determine the effect upon the dopamine response. The results found were compared with those of the appropriate diluent.

The effects of dopamine or norepinephrine on blood glycerol levels were also studied in a total of 20 animals. This was done by taking a control sample, injecting the appropriate catecholamine, and sampling again after $45 \mathrm{~min}$. The glycerol levels were measured by an enzymatic method (4).

The main study of the temperature response in BAT, lumbar muscle, and in core temperature was made in three stages after initiating the studies. These were at 10 days (rats $\simeq 42$ days old),
48 days (rats $\simeq 80$ days old), and at 90 days (rats $\simeq 120$ days old). The experiments were made at the same time daily. At each time interval (10,48, and 90 days) some of the untreated rats were killed and the interscapular brown fat pad was removed and weighed.

In general, the differences between each group was assessed by analysis of variance (14) using the Anova program of the BMDP package. Statistical significance was accepted at the $5 \%$ level.

\section{RESULTS}

Results are shown in Tables 1 and 2 and Figure 1. The core body temperatures, measured at $26^{\circ} \mathrm{C}$ room temperature for each group of animals before any drug treatment, are shown in Table 1, which also contains details of body weight increase and BAT yield. The last two figures were not always obtained from the same animals as the core temperatures, but they were obtained at the same experimental stage. Figure 1 shows a common response to the injection of catecholamine. The area between the two curves of Figure 1 (for BAT and lumbar muscle temperature) was calculated by the trapezoidal rule. This gave an integrated temperature difference $\left(\Delta \mathrm{BAT}-\right.$ muscle $\left.\mathrm{T}^{\circ} \mathrm{C}\right)$ for the effect in individual rats of either norepinephrine or dopamine. These values, as well as the maximum core temperature found after each type of injection are shown in Table 2 . The blood glycerol response (mean $\pm \mathrm{SD}$ ) to the catecholamines was as follows: control $0.55 \pm 0.2 \mathrm{mg} / 100 \mathrm{ml}$, after norepinephrine $8.9 \pm 1.76$ $\mathrm{mg} / 100 \mathrm{ml}$; control $0.55 \pm 0.21 \mathrm{mg} / \mathrm{ml}$, after dopamine $7.5 \pm$ $2.06 \mathrm{mg} / 100 \mathrm{ml}$. The difference from control was significant $(p$ $<0.0001$ ), but there was no difference between the response to dopamine or norepinephrine. The responses to dopamine given with the blocking agents were not consistent, the degree of blocking varying from $15 \pm 10 \%$ (propranolol) to $14 \pm 9 \%$ (phenoxybenzamine), with pimozide yielding a figure of $36 \pm$ $16 \%$ inhibition.

Table 1. Initial core temperatures at various stages, and wt of brown adipose tissue

\begin{tabular}{|c|c|c|c|c|}
\hline \multirow[b]{2}{*}{ Group } & & \multicolumn{3}{|c|}{ Duration of study } \\
\hline & & $\begin{array}{c}10 \\
\mathrm{~A} \\
\text { Age } \simeq 42 \\
\text { days }\end{array}$ & $\begin{array}{c}48 \\
\text { B } \\
\text { Age }=80 \\
\text { days }\end{array}$ & $\begin{array}{c}90 \\
C \\
\text { Age } \simeq 120 \\
\text { days }\end{array}$ \\
\hline $\begin{array}{l}1 . \\
\text { Control }\end{array}$ & Core $\mathrm{T}^{\circ} \mathrm{C}$ & $\begin{array}{c}38.3 \pm 0.13 \\
(n=34)\end{array}$ & $\begin{array}{r}38.3 \pm 0.1 \\
(n=90)\end{array}$ & $\begin{array}{c}38.5 \pm 0.13 \\
(n=43)\end{array}$ \\
\hline Room $\mathrm{T}^{\circ} \mathrm{C}$ & $\begin{array}{l}\text { Body wt }(\mathrm{g}) \\
\text { BAT }(\mathrm{mg})\end{array}$ & $\begin{array}{l}125 \pm 2.6 \\
190 \pm 6.0\end{array}$ & $\begin{array}{l}231 \pm 1.0 \\
240 \pm 5.0\end{array}$ & $\begin{array}{l}300 \pm 2.4 \\
277 \pm 2.0\end{array}$ \\
\hline $\begin{array}{l}2 . \\
\text { Control }\end{array}$ & Core $\mathrm{T}^{\circ} \mathrm{C}$ & $\begin{array}{c}38.2 \pm 0.16 \\
(n=14)\end{array}$ & $\begin{array}{r}39.3 \pm 0.2 \\
(n=13)\end{array}$ & $\begin{array}{r}38.5 \pm 0.2 \\
(n=10)\end{array}$ \\
\hline $4^{\circ} \mathrm{C}$ & $\begin{array}{l}\text { Body wt }(\mathrm{g}) \\
\text { BAT }(\mathrm{mg})\end{array}$ & $\begin{array}{l}108 \pm 4 \\
199 \pm 8\end{array}$ & $\begin{array}{l}225 \pm 4 \\
394 \pm 22\end{array}$ & $\begin{array}{l}268 \pm 6 \\
448 \pm 12\end{array}$ \\
\hline $\begin{array}{l}3 . \\
\text { Cafeteria }\end{array}$ & Core $\mathrm{T}^{\circ} \mathrm{C}$ & $\begin{array}{r}39.1 \pm 0.2 \\
(n=10)\end{array}$ & $\begin{array}{r}38.6 \pm 0.2 \\
(n=16)\end{array}$ & $\begin{array}{c}38.3 \pm 0.15 \\
(n=15)\end{array}$ \\
\hline $4^{\circ} \mathrm{C}$ & $\begin{array}{l}\text { Body wt }(\mathrm{g}) \\
\text { BAT }(\mathrm{mg})\end{array}$ & $\begin{array}{l}130 \pm 3 \\
315 \pm 15\end{array}$ & $\begin{array}{l}237 \pm 2.7 \\
639 \pm 30\end{array}$ & $\begin{array}{l}301 \pm 2.6 \\
624 \pm 12.6\end{array}$ \\
\hline $\begin{array}{l}4 . \\
\text { Cafeteria }\end{array}$ & Core $\mathrm{T}^{\circ} \mathrm{C}$ & $\begin{array}{r}38.9 \pm 0.2 \\
(n=10)\end{array}$ & $\begin{array}{c}38.5 \pm 0.14 \\
(n=30)\end{array}$ & $\begin{array}{r}38.1 \pm 0.4 \\
(n=11)\end{array}$ \\
\hline Room $\mathrm{T}^{\circ} \mathrm{C}$ & $\begin{array}{l}\text { Body wt }(\mathrm{g}) \\
\text { BAT }(\mathrm{mg})\end{array}$ & $\begin{array}{l}127 \pm 6.9 \\
303 \pm 2.2\end{array}$ & $\begin{array}{l}250 \pm 5 \\
387 \pm 11\end{array}$ & $\begin{array}{l}358 \pm 13.6 \\
664 \pm 54\end{array}$ \\
\hline
\end{tabular}

Values are group means with SE. Temperature comparisons-1A is control room $\mathrm{T}^{\circ} \mathrm{C}$ at 10 days, so $1 \mathrm{~A}$ vs $3 \mathrm{~A} p<0.005$; $1 \mathrm{~A}$ vs $4 \mathrm{~A} p<$ $0.05 ; 2 \mathrm{~A} v s 3 \mathrm{~A} p<0.005 ; 2 \mathrm{~A}$ vs $4 \mathrm{~A} p<0.05 ; 1 \mathrm{~B} v s 2 \mathrm{~B} p<0.001 ; 2 \mathrm{~B} v s$ 3B $p<0.05 ; 2 \mathrm{~B}$ vs 4B $p<0.02$.

The figures for body weight and BAT were obtained from different groups of rats. 
Table 2. Temperature responses to norepinephrine (NE) or dopamine (DOP) at various study stages

\begin{tabular}{|c|c|c|c|c|c|c|c|c|c|c|}
\hline \multirow[b]{2}{*}{ Group } & \multirow[b]{2}{*}{ Drug } & \multicolumn{3}{|c|}{$\begin{array}{l}\text { Duration of study }-10 \text { days } \\
\text { Age of rat }=42 \text { days }\end{array}$} & \multicolumn{3}{|c|}{$\begin{array}{l}\text { Duration of study }-48 \text { days } \\
\text { Age of rat }=80 \text { days }\end{array}$} & \multicolumn{3}{|c|}{$\begin{array}{l}\text { Duration of study }-90 \text { days } \\
\text { Age of rat } \simeq 120 \text { days }\end{array}$} \\
\hline & & $\Delta \mathrm{T}^{\circ} \mathrm{C} \mathrm{BAT} / \mathrm{mus}^{*}$ & Core $\mathrm{T}^{\circ} \mathrm{C} \max$ & $n$ & $\Delta \mathrm{T}^{\circ} \mathrm{C} \mathrm{BAT} / \mathrm{mus}$ & Core $\mathrm{T}^{\circ} \mathrm{C} \max$ & $n$ & $\Delta \mathrm{T}^{\circ} \mathrm{C} \mathrm{BAT} / \mathrm{mus}$ & Core $\mathrm{T}^{\circ} \mathrm{C} \max$ & $n$ \\
\hline $\begin{array}{l}\text { Control } \\
\text { Room } \mathrm{T}^{\circ} \\
\mathrm{C}\end{array}$ & $\begin{array}{l}\text { NE } \\
\text { DOP }\end{array}$ & $\begin{array}{l}1.03 \pm 0.60 \\
1.79 \pm 0.52\end{array}$ & $\begin{array}{l}40.78 \pm 1.00 \\
40.15 \pm 0.48\end{array}$ & 8 & $\begin{array}{l}2.04 \pm 0.42 \\
1.05 \pm 0.26 \dagger\end{array}$ & $\begin{array}{l}38.45 \pm 0.60 \\
38.89 \pm 0.26\end{array}$ & 11 & $\begin{array}{l}1.19 \pm 0.56 \\
0.93 \pm 0.24\end{array}$ & $\begin{array}{l}38.96 \pm 0.38 \\
38.56 \pm 0.14\end{array}$ & 10 \\
\hline $\begin{array}{l}\text { Control } \\
4^{\circ} \mathrm{C} \\
\text { Cafeteria } \\
4^{\circ} \mathrm{C}\end{array}$ & $\begin{array}{l}\text { NE } \\
\text { DOP } \\
\text { NE } \\
\text { DOP }\end{array}$ & $\begin{array}{l}1.35 \pm 0.58 \\
1.57 \pm 0.38 \\
0.75 \pm 0.40 \\
1.64 \pm 0.80\end{array}$ & $\begin{array}{l}41.72 \pm 0.28 \\
41.24 \pm 0.30 \\
42.54 \pm 0.40 \\
42.70 \pm 0.40\end{array}$ & 10 & $\begin{array}{l}1.30 \pm 0.32 \\
1.44 \pm 0.70 \\
1.74 \pm 0.70 \\
2.07 \pm 0.60\end{array}$ & $\begin{array}{l}40.27 \pm 0.80 \\
40.37 \pm 0.90 \\
40.98 \pm 1.10 \\
42.04 \pm 1.00\end{array}$ & 7 & $\begin{array}{l}1.03 \pm 0.46 \\
1.19 \pm 0.94 \\
2.14 \pm 0.56 \\
1.88 \pm 0.32\end{array}$ & $\begin{array}{l}39.98 \pm 1.00 \\
39.82 \pm 0.46 \\
40.70 \pm 0.32 \\
40.98 \pm 0.14\end{array}$ & 10 \\
\hline $\begin{array}{l}\text { Cafeteria } \\
\text { Room T } \\
\text { C }\end{array}$ & $\begin{array}{l}\text { NE } \\
\text { DOP }\end{array}$ & $\begin{array}{l}1.58 \pm 0.52 \\
2.08 \pm 0.54\end{array}$ & $\begin{array}{l}41.60 \pm 0.70 \\
41.30 \pm 1.00\end{array}$ & 10 & $\begin{array}{l}2.46 \pm 0.60 \\
2.17 \pm 0.50\end{array}$ & $\begin{array}{l}40.30 \pm 0.52 \\
40.15 \pm 0.80\end{array}$ & 13 & $\begin{array}{l}2.63 \pm 0.56 \\
2.01 \pm 0.44\end{array}$ & $\begin{array}{l}40.22 \pm 0.20 \\
39.20 \pm 0.40\end{array}$ & 13 \\
\hline
\end{tabular}

* Mean temperature difference between brown adipose tissue and lumbar muscle as shown in Figure 1.

Figures are group means with SE: $\nmid p$ value of NE vs DOP response $<0.05$.

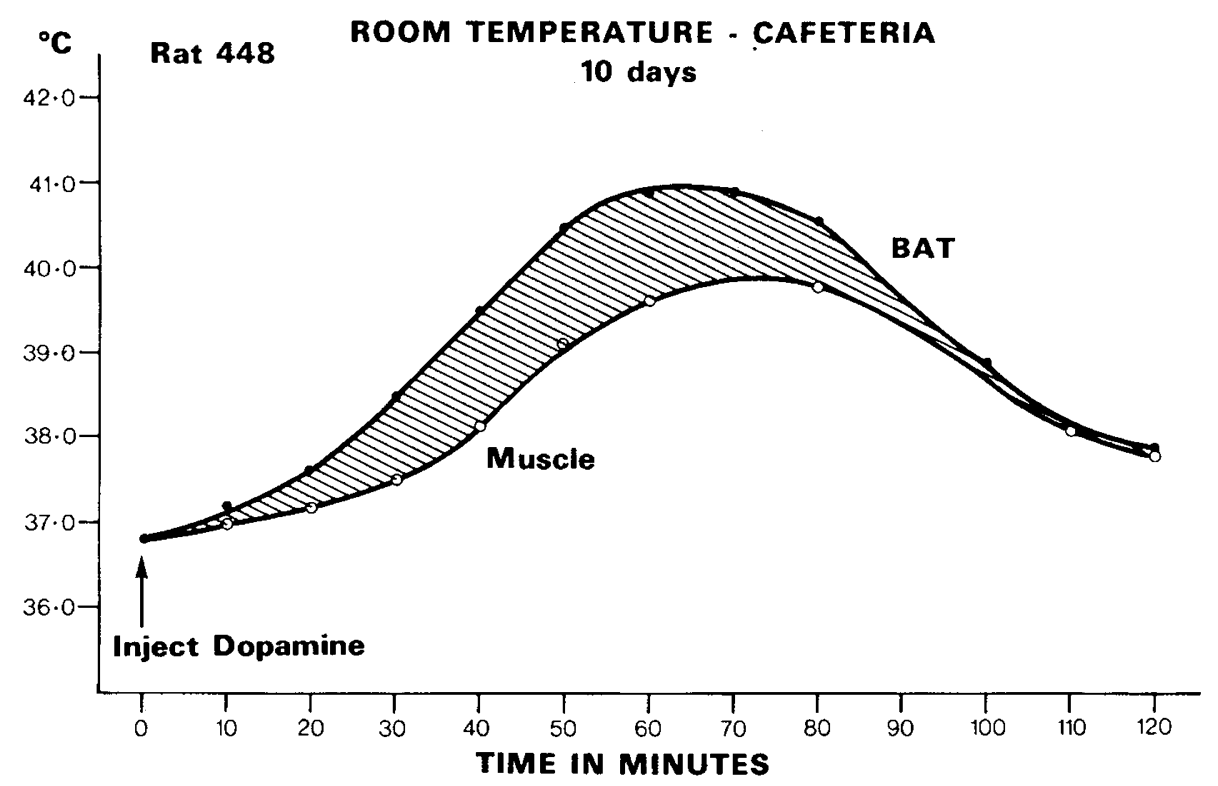

Fig. 1. Example of the temperature response in BAT and muscle after the injection of dopamine.

\section{DISCUSSION}

Table 1 shows the effect of time, environmental temperature, and dietary variation upon the weight gain, accumulation of interscapular BAT, and core temperature of the animals. The body weight gain shown in Table 1 is representative of the steady increase reported by us in an earlier study (13), i.e. weight gain was greatest in the room temperature cafeteria-fed animals, and least in the controls kept at $4^{\circ} \mathrm{C}$ (the last finding may represent the result of the demands made upon the animal to produce heat in the cold).

Interscapular brown adipose tissue was certainly present in each group, and its weight was greatest in the cold-stressed rats, or in those given a cafeteria diet. After 90 days, the weight of interscapular BAT found in cafeteria-fed animals kept at either 26 or $4^{\circ} \mathrm{C}$ was at least twice that found in the rat food-fed animals kept at $26^{\circ} \mathrm{C}$.

The core temperatures varied slightly from group to group but always showed a significant difference between the control or cafeteria-fed animals, whether they were kept at 26 or $4^{\circ} \mathrm{C}$. Table 1 shows that the differences were most marked in the 42-day-old animals after 10 days of treatment, but they largely disappeared in the older ( $~ 1120$ day old) animal after 90 days of treatment. These findings, previously unreported, are perhaps of intrinsic interest. However, their significance to us lies in our belief that such core temperature changes are not likely to invalidate the local temperature responses found over the interscapular BAT.
Figure 1 shows a representative illustration of the temperature change in interscapular BAT and lumbar muscle after dopamine. The change with norepinephrine is very similar. The response of the noncontracting muscle may reasonably be said to represent a vascular (vasodilator) response either to norepinephrine (1), or to dopamine (9), when used in the same dose as in the present study.

The effect of norepinephrine in raising the temperature of BAT is well known, and represents changes both in tissue perfusion and heat release in the tissue (3). Accordingly, we believe that the mean temperature difference (which is the area between the curves shown in Fig. 1) is a measure of the heat release, or thermogenic response to the drug studied. Although not shown in the results, we also calculated the difference between the maximum interscapular BAT temperature and the maximum muscle temperature. These latter differences gave values, or a measure of thermogenic effect, entirely akin to those derived as shown in Figure 1. This may strengthen the conclusions drawn from the values for mean temperature differences shown in Table 2 for the effects of the catecholamines given to the variously aged animals at the various stages of the study. Table 2 shows quite clearly that dopamine always exerts a thermogenic effect (as defined above). The response of the groups of animals given dopamine did not differ from the response to norepinephrine, with the sole exception of the 80-day-old control animals kept at room temperature. In that group, the dopamine effect was present, but was about half of that found in the group given norepi- 
nephrine. We do not think that this exception vitiates our general conclusion that dopamine has an effect upon interscapular BAT which is quantitatively similar to that of norepinephrine. The maximum core temperature shown in Table 2 was always less than the maximum recorded in the BAT; and the core temperature maxima were invariably attained $15-30$ min later than in the BAT or muscle. Table 2 then suggests that dopamine had an effect upon core temperature which was at least equal to that of norepinephrine. A rise in core temperature is regarded as a classic thermogenic effect of norepinephrine (2). If this is so, then our results suggest that dopamine, in this regard, is as effective as norepinephrine.

The final point we stress concerns the action of dopamine in increasing the glycerol levels in the rat. This effect is shared by norepinephrine in circumstances which suggest that glycerol is released from brown fat (3). Our study shows that the glycerolreleasing effect of dopamine is as great as is that of norepinephrine. While this does not prove that this effect of dopamine is exerted upon BAT, it is certainly coincident in time with the rise in temperature induced in BAT by dopamine. We suggest then that our hypothesis of glycerol release by dopamine from BAT warrants further direct exploration.

Thus, we believe that there is evidence that dopamine can increase core temperature, BAT temperature, and cause glycerol release. These effects are akin to those of norepinephrine, and suggest that dopamine can exert a thermogenic effect upon BAT. Rothwell et al. (11) observed an increase in whole body oxygen consumption following the subcutaneous injection of dopamine into rats with stores of BAT. This gives somewhat indirect evidence of a dopamine effect upon thermogenesis. Thus dopamine, or for that matter norepinephrine, will increase whole body oxygen consumption in animals who have low, or no, stores of BAT. Examples of this effect include the action of dopamine in the adult dog (8), or that of norepinephrine in adult humans (5). We believe then that our study represents direct evidence of the action of dopamine upon brown adipose tissue. The mechanism of the action of dopamine is open to further discussion. Thus, the effect is not consistently blocked by $\alpha$ - or $\beta$-blocking agents, or in our study, by the dopamine blocker pimozide. The latter drug was reported (11) to inhibit the increase in whole body oxygen consumption induced by dopamine, but for the reasons noted above, this may be a nonspecific reaction. It seems likely then that the nature of the dopamine effect will ultimately rest upon the demonstration of blocking effects in a simpler, perhaps in vitro, system. A more satisfactory proof would be to demonstrate the presence of dopamine receptors in the brown adipocyte itself. However, if the mechanism is still obscure, the effect seems to be definite, i.e. dopamine can exert a thermogenic effect on rat BAT. Since dopamine is present in large quantity in the urine of human newborns $(8)$ it is not then too unreasonable to suggest that the two observations are related, and that dopamine, as well as norepinephrine, can help mobilize energy from BAT in the human infant.

\section{REFERENCES}

1. Berne RM, Levy MN 1972 Special circulations. In: Cardiovascular Physiology 2nd ed. CV Mosby Co, St. Louis, 1972, p 222

2. Bukowiecki L, Collet AJ, Follea N, Guay G, Jahjah L 1982 Brown adipose tissue hyperplasia: a fundamental mechanism of adaptation to cold and hyperphagia. Am J Physiol 242:E353-E359

3. Cottle WH 1970 The innervation of brown adipose tissue. In: Lindberg O (ed) Brown Adipose Tissue. Elsevier, New York, 1970, pp 155-176

4. Eggstein M 1966 Eine neue Bestimmung der Neutralfette im Blutserum und Gewebe. I. Prinzip, Durchführung und Besprechung der Methode. Klin Wochenschr 44:262

5. Goldenberg M, Pines KL, Baldwin EDeF, Greene DG, Roh CE 1948 The hemodynamic response of man to nor-epinephrine and epinephrine and its relationship to the problem of hypertension. Am J Med 6:792

6. Hull D 1966 The structure and function of brown adipose tissue. Br Med Bull 22:92

7. Hull D, Hardman MJ 1970 Brown adipose tissue in newborn mammals. In: Lindberg O (ed) Brown Adipose Tissue. Elsevier, New York, 1970, pp 97115

8. Maxwell GM, Crompton S 1981 The urinary catecholamines of normal and abnormal newborns. Aust Paediatr J 17:228

9. Maxwell GM, Rowe GG, Castillo CA, Clifford JE, Afonso S, Crumpton CW 1960 The effect of dopamine (3-hydroxytyramine), upon the systemic pulmonary and cardiac haemodynamics and metabolism of intact dog. Arch Int Pharmacodyn Ther 129:62

10. Rothwell MJ, Stock MJ 1979 A role for brown adipose tissue in diet-induced thermogenesis. Nature 281:31

11. Rothwell MJ, Stock MJ, Wyllie MG 1982 Dopaminergic mechanisms in dietinduced thermogenesis and brown adipose tissue metabolism. Eur J Pharmacol 77:45

12. Sclafani A, Springer D 1976 Dietary obesity in adult rats: similarities to hypothalamic and human obesity syndromes. Physiol Behav 17:461

13. Smyth C, Crompton S, Harvey G, Maxwell GM 1983 Methods of producing brown adipose tissue in rats. Proc Aust Soc Clin Exp Pharmacol 13:87

14. Snedecor GW, Cochran WG 1967 Statistical Methods 6th ed. Iowa State University Press, Ames, IA

15. Steiner G' 1975 Neural and humoral regulation of brown adipose tissue metabolism. In: Temperature Regulation and Timing Action. Karger, Basel pp 159-171 